\title{
Performance native chicken treated by different stocking density and litter type
}

\author{
Dwi Rohmadi*1), Sri Harimurti ${ }^{2)}$ and Wihandoyo ${ }^{2)}$ \\ ${ }^{1)}$ Gorontalo Assessment Institute of Agricultural Technology, Jl. Muh Van Gobel 270, Bone \\ Bolango 96554, Gorontalo, Indonesia \\ 2) Department of Poultry Science, Faculty of Animal Science, Universitas Gadjah Mada, Jl. \\ Fauna 03 Kampus UGM Bulaksumur Sleman 55281, Yogyakarta, Indonesia
}

Submitted: 24 February 2020, Accepted: 05 July 2021

\begin{abstract}
This research was aimed to determine the effect of different stocking density and different litter materials on the production performance of native chicken. Material of yhis study was 324-day old chick (DOC) native chickens, reared for 12 weeks. The DOC were randomly devided into 9 treatment groups include a combination of 3 stocking density $(8,12$ and $16 \mathrm{bird} / \mathrm{m}^{2}$ ) and 3 litter materials (rice hulls, wood shavings and corncobs) in 3 replication. A completely randomized factorial design was an applied in the study then followed by Duncan's multiple range tests. The parameters observed were feed consumption ( $\mathrm{g} / \mathrm{bird} / 12$ weeks), body weight gain (g/bird), feed conversion ratio, and mortality $(\%)$. The results showed that feed consumption had affected by stocking density $(\mathrm{p}<0.05)$, but it had not affected by litter materials type. Feed consumption at densities of 8,12 and $16 \mathrm{bird} / \mathrm{m}^{2}$ was $3890 ; 4020$ and $4061 \mathrm{~g} / \mathrm{bird}$ respectively. The highest feed consumption was obtained at a density of $16 \mathrm{bird} / \mathrm{m}^{2}$. Weight gain, feed conversion and mortality had not affected by stocking density and litter material. It can concluded that the body weight gain, feed intake, feed conversion ratio and mortality is same for stocking density 8,12 and $16 \mathrm{bird} / \mathrm{m}^{2}$ an $\mathrm{d}$ same for litter type of rice hulls, wood shaving and corncob.
\end{abstract}

Keywords: litter material; Native chicken; Performance; Stocking density

*Corresponding Author: dwibptp@gmail.com 


\section{INTRODUCTION}

Native chicken is a local Indonesian chicken that widely kept by people in the villages. Today's intensive rearing of native chicken was significantly increased. This is due to the increase of consumer demand and product prices relatively stable. This is illustrated by the increasing population of native chickens, as much 285.3 million in 2015 to 310.9 million in 2018 (Anonymous, 2018).

Constrain on intensive rearing of native chicken was of floor space. Increasing the stock density up to 16 birds/ $\mathrm{m}^{2}$ was needed but the comfortable of chickens still being focused. Pens with high density made the chicken uncomfortable because it's increased the competition in getting food, drinking water and oxygen. This competition resulting in non-uniform growth performance especially in male and female broiler chickens (Zuowei et al., 2011). Stocking density level of cages 8,10 and $12 \mathrm{birds} / \mathrm{m}^{2}$ in native chickens were not influenced by the amount of feed consumption, drinking water consumption, body weight, body weight gain, feed conversion and mortality (Mahmud et al., 2017)

Intensive maintenance of native chickens generally used open cages and using litter as bedding material. The litter material always used rice hulls, but rice hulls materials today were made to become competing with other businesses. Actually, litter material can be used the other materials such as wood shaving or corncob, other materials that can be used as litter were rice straw, wheat straw, sand, agricultural crop waste, chopped corncobs, paper chips, tea pulp and coconut fiber (Garcês, et al, 2013).

The ideal litter material requirements must be dry with a high water-holding capacity but should also be able to absorbed moisture quickly (Atapattu \& Wickramasinghe, 2007). Rice hulls litter material increasingly expensive and difficult to obtain so it needs to replace with the other sources of litter material as an alternative with abundant availability including wood shavings and corncobs.

There was no more research on stocking density and litter type materials for native chickens. It was necessary to research about the effect of various stocking density and different litter types on the performance of native chickens.

\section{MATERIALS AND METHODS}

This study used day old chicken native chicken, a total of 324. The native chicken variety used in the research is Kampung Unggul Balitbangtan (KUB). Feed with crude protein $16.26 \%$; Metabolized energy $2894.1 \mathrm{kcal} / \mathrm{kg}$; calcium $1.63 \%$; phosphor $0.58 \%$; Lysine $0.85 \&$ and Methionine $0.30 \%$, details in tables 1 and 2 .

The 324 doc was randomly into 9 treatment groups (3 stock density densities and 3 litter materials) in 3 times replication. There are 3 densities groups of 8, 12 and 16 $\mathrm{bird} / \mathrm{m}^{2}$ with litter materials of rice hulls, wood shavings, and corncobs. The moisture content of the three types of litter material was equal to $10 \%$. The mass $(\mathrm{kg})$ of wood shavings with a thickness of $12 \mathrm{~cm}$ in depth/square meter, equivalent to a weight of $12.8 \mathrm{~kg}$, was used as a reference for the use of rice hulls and corncobs. This research used an open cage with a monitor roof and litter floor in $1 \mathrm{~m}^{2}(1 \times 1 \mathrm{~m})$ with a height of $2 \mathrm{~m}$.

The data collected were Measurement variables were feed consumption, body weight gain, feed conversion ratio, mortality and other data is duodenal histology. Completely Randomized Design 3 x 3 Factorial, (3 stocking density and 3 types of litter material) and repeated 3 times replication. Design was used was applied in the study and followed by DMRT. Histology preparations was carried out from $1 \mathrm{~cm}$ long pieces for each sample from the duodenal then fixed in $10 \%$ buffered formalin, soaked for 24 to 48 hours, then made histological preparations. Each piece of tissue sample is hydrated which is passed one by one in an alcohol series with concentrated levels 
ranging from $30 \%, 50 \%, 70 \%, 80 \%, 95 \%$, and $100 \%$. Each of the above samples is transferred one by one into each alcohol concentration for about 10 seconds. Then the sample is put in xylene and finally dipped in paraffin. Samples were sliced with $4 \mu \mathrm{m}$ thickness using microtome and histological process followed AlcianBlue stained. Histological preparations in object glass observed and measured using a microscope with the help of a computer. Take a sample area of $1 \mathrm{~mm}$ and counting the number of visible goblet cells under microscope electron.

Table 1. Ration composition

\begin{tabular}{lc}
\hline \multicolumn{1}{c}{ Feed Ingredient } & Proportion $(\%)$ \\
\hline Yellow Corn & 56.81 \\
Bran & 21.95 \\
Meat bone meal & 6.32 \\
Soybean meal & 13.50 \\
Calcium & 0.13 \\
Premix vitamin & 0.42 \\
DL - methionine & 0.19 \\
L- lysin HCL & 0.68 \\
Total $(\%)$ & 100.00 \\
\hline
\end{tabular}

Table 2. Content of nutrient rations

\begin{tabular}{|c|c|}
\hline Nutrient content & Total $(\%)$ \\
\hline Dry ingredients $(\%)^{1)}$ & 90.00 \\
\hline Metabolic Energy $(\mathrm{kcal} / \mathrm{kg})^{2)}$ & 2894.1 (kcal) \\
\hline Crude Protein $(\%)^{1)}$ & 16.26 \\
\hline Crude fat $(\%)^{1)}$ & 3.46 \\
\hline $\operatorname{Ash}(\%)^{1)}$ & 8.28 \\
\hline Crude Fiber $(\%)^{1)}$ & 10.00 \\
\hline Calcium $(\%)^{3)}$ & 1.63 \\
\hline Phosphorus $(\%)^{3)}$ & 0.58 \\
\hline Methionine (\%) ${ }^{3)}$ & 0.30 \\
\hline Lysin $(\%)^{3)}$ & 0.85 \\
\hline
\end{tabular}

\section{RESULT AND DISCUSSION}

The production performance of native chickens that rearing until 12 weeks were shown in Table 3.

\section{Feed consumption}

Different levels of stocking density resulting significantly difference on feed consumption $(\mathrm{P}<0.05)$, but litter material had not affected feed consumption. Feed consumption at densities of 8,12 and 16 $\mathrm{bird} / \mathrm{m}^{2}$ were $3890 ; 4020$ and $4061 \mathrm{~g} / \mathrm{bird}$ (Table 3), shown that the increase of stocking density also increases the feed consumption. The more feed consumption at the density of 16 was caused by more competition to get feed than the other density. Another factor was caused higher density of chicken made busy sound can attract to eat feed more. (Aplleyby et al., 2004) states that the vision and sound of chickens that were eating trigger the other chickens to eat.

The different types of litter had not to affect feed consumption, because different litter materials did not change the pens comforting. One of the behavioral expressions can be seen from the feeding and foraging activities. (ElKhloya, 2017) reported that wood shavings, rice hulls, and corn stalks materials did not affect the 
proportion of feeding and foraging, which was $11.70 ; 13.70 ; 11.38$ for feeding and 5.8; 5.53 ; 5.68 for foraging. One factor that can affect consumption are chicken health and environmental (Muharlien et al., 2011). Stocking density and litter type did not have affected interaction for feed consumption.

\section{Weight gain}

The final weights were 1018, 1004 and 1038 grams for densities of 8,12 and 16 $\mathrm{bird} / \mathrm{m}^{2}$, the weight gain based on litter type is $980 ; 1041$ and 1040 for rice hulls, wood shaving, and corncob. The stocking density and the different litter type had not significantly affect weight gain. It showed that the density of the pens had no direct effect on weight gain because weight gain was more determined by the consumption of feed, especially protein. Protein was needed to maintain basic life, muscle and bone growth (Leeson \& Summers, 2005). Protein consumption for 12 weeks was 632.4; 653.7 and $660.4 \mathrm{~g}$ for densities of 8,12 and 16 $\mathrm{bird} / \mathrm{m}^{2}$ respectively.

Table 3. Performance of native chickens with different stocking density and litter material

\begin{tabular}{|c|c|c|c|c|}
\hline Treatments & $\begin{array}{c}\text { Feed } \\
\text { consumption } \\
(\mathrm{g} / \text { chick })\end{array}$ & $\begin{array}{l}\text { Weight gain } \\
\text { (g/ chick) }\end{array}$ & $\begin{array}{c}\text { Feed } \\
\text { conversion } \\
\text { ratio }\end{array}$ & Mortality (\%) \\
\hline \multicolumn{5}{|l|}{ Stocking density $\left(\mathrm{bird} / \mathrm{m}^{2}\right)$} \\
\hline 8 & $3890 \pm 14^{\mathrm{b}}$ & $1018 \pm 11$ & $3.85 \pm 0,33$ & $0.00 \pm 00$ \\
\hline 12 & $4020 \pm 82^{\mathrm{a}}$ & $1004 \pm 80$ & $4.02 \pm 0,26$ & $0.93 \pm 2,78$ \\
\hline 16 & $4061 \pm 28^{a}$ & $1038 \pm 52$ & $3.92 \pm 0,20$ & $0.69 \pm 2,08$ \\
\hline \multicolumn{5}{|l|}{ Litter type } \\
\hline Rice hull (RH) & $3966 \pm 11$ & $980 \pm 61$ & $4.06 \pm 0,23$ & $0.00 \pm 00$ \\
\hline Wood shaving (WS) & $4014 \pm 78$ & $1041 \pm 90$ & $3.88 \pm 0,29$ & $0.69 \pm 2.08$ \\
\hline Corncob (CC) & $3993 \pm 16$ & $1040 \pm 89$ & $3.86 \pm 0,27$ & $0.93 \pm 2.78$ \\
\hline \multicolumn{5}{|l|}{ Stocking density $\mathrm{x}$ Litter type } \\
\hline $8 \times \mathrm{RH}$ & $3866 \pm 37$ & $1000 \pm 62$ & $3.87 \pm 0,20$ & $0.00 \pm 00$ \\
\hline $8 \times \mathrm{WS}$ & $3959 \pm 12$ & $1052 \pm 15$ & $3.80 \pm 0,42$ & $0.00 \pm 00$ \\
\hline $8 \times \mathrm{CC}$ & $3844 \pm 22$ & $1003 \pm 15$ & $3.87 \pm 0,45$ & $0.00 \pm 00$ \\
\hline $12 \times \mathrm{RH}$ & $3962 \pm 14$ & $932 \pm 59$ & $4.26 \pm 0,12$ & $0.00 \pm 00$ \\
\hline $12 \times \mathrm{WS}$ & $4038+20$ & $1023 \pm 87$ & $3.97 \pm 0,34$ & $0.00 \pm 00$ \\
\hline $12 \times \mathrm{CC}$ & $4062 \pm 17$ & $1059 \pm 36$ & $3.84 \pm 0,12$ & $0.69 \pm 2.08$ \\
\hline $16 \times \mathrm{RH}$ & $4069 \pm 13$ & $1009 \pm 49$ & $4.04 \pm 0,19$ & $0.00 \pm 00$ \\
\hline $16 \times \mathrm{WS}$ & $4044 \pm 43$ & $1048 \pm 32$ & $3.86 \pm 0,12$ & $0.93 \pm 2.78$ \\
\hline $16 \times \mathrm{CC}$ & $4072 \pm 23$ & $1058 \pm 73$ & $3.86 \pm 0,26$ & $0.00 \pm 00$ \\
\hline \multicolumn{5}{|l|}{ Anova } \\
\hline Stocking density & 0,05 & n.s & n.s & n.s \\
\hline Litter type & n.s & n.s & n.s & n.s \\
\hline $\begin{array}{l}\text { Stocking density } \mathrm{x} \text { Litter } \\
\text { type }\end{array}$ & n.s & n.s & n.s & n.s \\
\hline
\end{tabular}

$\overline{a, b, c}$ Mean within columns with different superscripts are significantly different $(\mathrm{P}<0.05$, $\mathrm{P}<0.001$ ), n.s: no significant

The results of these experiments agreed with those of (Na-lampang, 2014) he reported similar body weight and body weight gain for Thai crossbred chicken reared at three-level density 8,12 , and 16 bird $/ \mathrm{mm}^{2}$ result not significant. However, (Jobe et al., 2019) reported a significant decrease of average weight gain of indigenous chicken in stocking density 20 than 5 and $10 \mathrm{bird} / \mathrm{m}^{2}$. 


\section{Feed Conversion Ratio}

The feed conversion ratio had not affected by stocking density. The feed conversion ratio for densities of 8,12 and 16 birds $/ \mathrm{m}^{2}$ is $3.85 ; 4.02$ and 3.92 respectively. Stocking density and type of litter material had not significantly affected the feed conversion on this study. Because of the chicken comfortable in the pen and had no become stress. It can be seen from the equal height, width of the villi and the depth of crypt in the duodenal segment of all treatment (Table 4). The increase of villi height in the chicken intestine was parallel with the increasing of digestive and absorption function that expresses the nutrient transport system throughout the body (Awad et al., 2006).

Table 4. Average villus height, villus width, crypt depth and goblet cell density of duodenal

\begin{tabular}{lcccc}
\hline Treatments & $\begin{array}{c}\text { Villus } \\
\text { height }(\mu \mathrm{m})\end{array}$ & $\begin{array}{c}\text { Villus width } \\
(\mu \mathrm{m})\end{array}$ & $\begin{array}{c}\text { Crypt } \\
\text { depth }(\mu \mathrm{m})\end{array}$ & $\begin{array}{c}\text { Goblet cell density } \\
\left(\mathrm{n} / \mathrm{mm}^{2}\right)\end{array}$ \\
\hline Stocking density & $\left(\right.$ birds $\left./ \mathrm{m}^{2}\right)$ & & & \\
8 & $1316.1 \pm 121.5$ & $209.7 \pm 32.1$ & $259.6 \pm 18.2$ & $530.7 \pm 197.9$ \\
12 & $1262.5 \pm 109.9$ & $220.7 \pm 26.9$ & $254.8 \pm 34.2$ & $623.2 \pm 278.2$ \\
$\quad 16$ & $1342.4 \pm 80.6$ & $218.0 \pm 18.9$ & $261.6 \pm 15.3$ & $723.3 \pm 258.5$ \\
Litter type & & & & \\
$\quad$ Rice hull (RH) & $1339.8 \pm 112.4$ & $217.9 \pm 27.6$ & $249.2 \pm 20.2$ & $604.3 \pm 259.9$ \\
$\quad$ Wood shaving & $1293.1 \pm 88.5$ & $214.4 \pm 23.6$ & $257.0 \pm 18.3$ & $521.2 \pm 196.0$ \\
$\quad$ WS & $1288.1 \pm 121.5$ & $216.0 \pm 29.3$ & $269.7 \pm 15.3$ & $751.6 \pm 260.2$ \\
\hline Corncob (CC) & &
\end{tabular}

$\overline{\mathrm{a}, \mathrm{b}, \mathrm{c}}$ Mean within columns with different superscripts are significantly different $(\mathrm{P}<0.05)$

Using wood shavings, rice hulls, bagasse, and wheat straw in broiler chickens did not affect feed conversion (Monira et al., 2003). The use of rice husk litter, softwood sawdust, wood shavings, hardwood sawdust, pieces of paper, chopped straw and recycled litter had not significantly affect the conversion of chicken feed of 28 days (Torok et al., 2009). The stressor pressure mechanism in increasing stocking density had not influenced the intestinal morphology. It can be seen that in all treatment, the small intestine segments have the same villi height and villi width (Table 4). This indicated that stocking density of 16 birds $/ \mathrm{m}^{2}$, did not change the condition of the digestive tract.

The height and width of the villus affect the nutrient uptake process which provides growth and feed efficiency. Increasing the height and width of the villus increases the surface area of the villus for absorption of nutrients in the digestive process (Miles et al., 2006). The width and height of the duodenal villus in this study were the same so that the same feed efficiency was produced, where in the end feed conversion ratio was not significantly different.

\section{Mortality}

The stocking density and the different types of litter material did not give a significant difference to the mortality of chickens. The consecutive mortality was 0 ; 0.93 and $0.69 \%$ for densities 8, 12 and 16 bird $/ \mathrm{m}^{2}$ and $0 ; 0.69$ and $0.93 \%$ for litter Rice hulls, wood shaving and corncob (Table 3 ). This same mortality is possible because at different densities and types of litter chickens have the same Goblet cell density. The same goblet cell density at the level of cage density and type of litter can protect chickens from various pathogens that can cause death. High stocking density will reduce the performance of chickens and have a negative effect by disrupting the intestinal barrier function (Goo et al., 2019).

The Goblet cells secreted gel-shaped glycoprotein mucus to protect intestinal epithelial cells from invader invasion, including worm invasion (Balqis et al., 2007). When an infection occurs, Goblet 
cells will undergo proliferation which aims to maintain life from this infection. Goblet cell proliferation plays a role in the removal mechanism of mucin produced by Goblet cells continuously producing mucus that can trap pathogens (Balqis et al., 2015)

The different types of litter had not significantly affected mortality, this shows that the three litter materials are suitable to be used. In the same research (Toghyani et al., 2010) compared wood shavings litter, rice hulls, paper rollers, sand, and no litter showed no different results in mortality. (Ali et al., 2012) using a stocking density of $0.186 ; 0.279$ and $0.372 \mathrm{~m}^{2} /$ bird rearing up to 2-6 months did not affect mortality, while this study used a density of 8,12 and bird $/ \mathrm{m}^{2}$ (0.125; 0.083 and $0.063 \mathrm{~m}^{2} /$ bird).

\section{CONCLUSIONS}

As the basis of present findings, it was concluded that the body weight gain, feed intake, feed conversion ratio and mortality is same for stocking density 8,12 and 16 $\mathrm{bird} / \mathrm{m}^{2}$ an d same for litter type of rice hulls, wood shaving and corncob.

\section{ACKNOWLEDGMENT}

The acknowledgment was awarded to Indonesian Agency for Agricultural Research and Development for the research grant.

\section{REFERENCES}

Ali, M. I., Azmal, S., Ali, A., \& Faruque, M. O. (2012). Effect of density and flock size on growth performance of native chicken. Journal of the Bangladesh Agricultural University, 10(1), 55-59. https://doi.org/10.3329/jbau.v10i1.12040

Anonymous. (2018). Statistik Peternakan dan Kesehatan Hewan. Direktorat Peternakan dan Kesehatan Hewan.

Aplleyby, M. C., Mench, J. A., \& Hughes, B. O. (2004). Poultry Behaviour and Welfare (M. C. Appleby, J. A. Mench, \& B. O. Hughes (eds.)). CABI. https:// doi.org/10.1079/9780851996677.0000

Atapattu, N. S. B. M., \& Wickramasinghe, K. P. (2007). Production, modeling, and education the use of refused tea as litter material for broiler chickens. Poultry Science, 86, 968-972.

Awad, W. A., Böhm, J., Razzazi-Fazeli, E., Ghareeb, K., \& Zentek, J. (2006). Effect of addition of a probiotic microorganism to broiler diets contaminated with deoxynivalenol on performance and histological alterations of intestinal villi of broiler chickens. Poultry Science, 85(6), 974979. https://doi.org/10.1093/ps/85.6.974

Balqis, U., Hanafiah, M., Januari, C., Salim, M. N., Aisyah, S., \& Fahrimal, Y. (2015). Jumlah sel goblet pada usus halus ayam kampung (Galludomesticus) yang terinfeksI Ascaridia galli secara alami. Jurnal Medika Veterinaria, 9(1), 19992002. https://doi.org/10.21157/j.med. vet..v9i1.3001

Balqis, U., Tiuria, R., \& Priosoeryanto, B. P. (2007). Goblet cells proliferation of duodenum, jejunum, and ileum of laying hens immunized with protein of excretory-secretory of ascaridia galli. Jurnal Kedokteran Hewan Indonesian Journal of Veterinary Sciences, 1(2), 70-75. https://doi. org/10.21157/j.ked.hewan.v1i2.3129

ElKhloya, S. (2017). Do alternative litter materials affect performance, welfare and immune response of broiler chicks?. Alexandria Journal of Veterinary Sciences, 52(1), 133. https://doi.org/10.5455/ajvs.256271

Garcês, A. P. J. T., Afonso, S. M. S., Chilundo, A., \& Jairoce, C. T. S. (2017). Evaluation of different litter materials for broiler production in a hot and humid environment: 2 . Productive performance and carcass characteristics. Tropical Animal Health and Production, 49(2), 369374. https://doi.org/10.1007/s11250016-1202-7

Goo, D., Kim, J. H., Choi, H. S., Park, G. H., Han, G. P., \& Kil, D. Y. (2019). Effect of stocking density and sex on growth performance, meat quality, and intestinal barrier function in broiler chickens. 
Poultry Science, 98(3), 1153-1160. https://doi.org/10.3382/ps/pey491

Jobe, M. C., Ncobela, C. N., Kunene, N. W., \& Opoku, A. R. (2019). Effects of Cassia abbreviata extract and stocking density on growth performance, oxidative stress and liver function of indigenous chickens. Tropical Animal Health and Production, 51(8), 25672574. https://doi.org/10.1007/s11250019-01979-y

Leeson, S., \& Summers, J. D. (2012). Commercial Poultry Nutrition Third Edition. Nottingham University Press. https://doi.org/10.7313/UPO9781904 761099

Lisnahan, C. (2018). Penentuan Kebutuhan Nutien Ayam Kampung Fase Pertumbuhan Yang Dipelihara Secara Intensif dengan Metode Kafetaria. Universitas Gajah Mada.

Mahmud, A. T. B. A., Afnan, R., Ekastuti, D. R., \& Arief, I. I. (2017). Profil darah, performans dan kualitas daging ayam persilangan kampung broiler pada kepadatan kandang berbeda. Jurnal Veteriner, 18(2), 247. https://doi.org/10.19087/jveteriner.20 17.18.2.247

Miles, R. D., Butcher, G. D., Henry, P. R., \& Littell, R. C. (2006). Effect of antibiotic growth promoters on broiler performance, intestinal growth parameters, and quantitative morphology. Poultry Science, 85(3), 476-485. https://doi.org/10.1093/ps/85.3.476

Monira, K. N., Islam, M. A., Alam, M. J., \& Wahid, M. A. (2003). Effect of litter materials on broiler performance and evaluation of manureal value of used litter in late autumn. AsianAustralasian Journal of Animal Sciences, 16(4), 555-557. https:// doi.org/10.5713/ajas.2003.555

Muharlien, Achmanu, \& R.Rachmawati. (2011). Meningkatkan produksi ayam pedaging melalui pengaturan proporsi sekam, pasir dan kapur sebagai litter. Jurnal Ternak Tropika, 12(1), 38-45.

Na-Lampang, P. (2014). Productivity and tonic immobility duration of thai crossbred chickens raised at different stocking densities. Global Journal of Animal Scientific Research, 2(2), 72-75.

NRC. (1994). Nutrient Requirements of Poultry. National Academies Press.

Toghyani, M., Gheisari, A., Modaresi, M., Tabeidian, S. A., \& Toghyani, M. (2010). Effect of different litter material on performance and behavior of broiler chickens. Applied Animal Behaviour Science, 122(1), 48-52. https://doi.org/10.1016/j.applanim.20 09.11 .008

Torok, V. A., Hughes, R. J., Ophel-Keller, K., Ali, M., \& MacAlpine, R. (2009). Influence of different litter materials on cecal microbiota colonization in broiler chickens. Poultry Science, 88(12), 2474-2481. https://doi.org/10. 3382/ps.2008-00381

Zuowei, S., Yan, L., Yuan, L., Jiao, H., Song, Z., Guo, Y., \& Lin, H. (2011). Stocking density affects the growth performance of broilers in a sexdependent fashion. Poultry Science, 90(7), 1406-1415. https://doi.org/10.3 382/ps.2010-01230 